\title{
ETS-Related Transcription Factor Elf-3
}

National Cancer Institute

\section{Source}

National Cancer Institute. ETS-Related Transcription Factor Elf-3. NCI Thesaurus. Code C20900.

ETS-related transcription factor Elf-3 (371 aa, $41 \mathrm{kDa}$ ) is encoded by the human ELF3 gene. This protein plays a role in the positive regulation of transcription. 